\title{
PHOTO-DEGRADATION OF SURFACTANT COMPOUNDS USING UV RAYS WITH ADDITION OF TIO 2 CATALYSTS IN LAUNDRY WASTE
}

\author{
Hendra, Eri Barlian, Abdul Razak, Hary Sanjaya \\ Program Studi Ilmu Lingkungan Program Pascasarjana \\ Universitas Negeri Padang. Jl Prof. Dr Hamka Padang. \\ Email: hary.s@fmipa.ac.id
}

\begin{abstract}
The utility of synthetic cleaners or commonly called as detergents have developed far indeed in this century. The effective and efficient use of detergents in cleaning process, was attracted to be used in laundry's industry commercially, though, it has some drawback to the society and environments. Since the active materials in the compounds can cause irritating to the skins, cataracts to mature eyes and some other environmental issues due to the excess of foams can prevent oxygen dilution in the water so it be hazardous to water living organisms. Once the promising method to solve this problem is by photo-degradation using photo-catalyst. Photocatalyst is the process using light and catalyst in order to accelerate chemical transformation, thus, solar or uv-rays can be used as light sources. This research aims at to show the ability of catalyst $\mathrm{TiO}_{2}$ to degrade active material in linear alkyl benzene sulphonate (LAS) and alkyl benzene sulphonate (ABS) which is available in commercial detergent. Photo-degradation of LAS and ABS compounds was determined by optimum capacity $\mathrm{TiO}_{2}$ and irradiance time. Whereas, for environmental application, the degrade compounds such Rinso ${ }^{\circledR}$ and Wipol ${ }^{\circledR}$ was chosen since it is commonly used in daily life. Beside, artificial water waste and laundry water was chosen to show the environmental effect. The result shows that the optimum number of catalyst $\mathrm{TiO}_{2}$ addition for LAS degradation was $1.5 \mathrm{~g}$, and optimum time was 120 minute. Whereas the optimum number of catalyst $\mathrm{TiO}_{2}$ addition for ABS degradation was $2.0 \mathrm{~g}$, and optimum time was 120 minute as well. Thus, for detergent Rinso ${ }^{\circledR}$, at optimum catalyst addition, we found degradation number was $75.83 \%$, and for detergent Wipol®, at optimum catalyst addition, we found degradation number was $57.94 \%$. Whereas, for artificial waste at optimum catalyst addition, we found degradation number was $91.32 \%$, and for laundry water waste at optimum catalyst addition, we found degradation number was $70.27 \%$.
\end{abstract}

Key words : Photodegradation, surfactant, $\mathrm{TiO}_{2}$, photocatalyst

\section{PENDAHULUAN}

Pemakaian bahan pembersih sintesis yang dikenal dengan detergen makin marak di masyarakat luas. Hal ini mulai menimbulkan dampak baik secara langsung maupun tidak langsung terhadap manusia dan lingkungannya. Sifat aktif dari detergen sangat efektif dalam membersihkan kotoran sehingga digunakan dalam proses pencucian. Dalam hal lain senyawa-senyawa yang terkandung didalam detergen dapat menimbulkan gangguan kesehatan terhadap manusia seperti iritasi pada kulit, penyebab katarak pada mata orang dewasa dan menimbulkan gangguan terhadap lingkungan seperti adanya busa-busa pada permukaan air sehingga mengurangi kadar oksigen terlarut dalam air (Sugiharto, 1987).

Dalam detergen terkandung komponen utamanya, yaitu surfaktan, baik bersifat kationik, anionik maupun non-ionik. Surfaktan merupakan zat aktif permukaan yang termasuk bahan kimia organik. Linear Alkylbenzene Sulfonate (LAS) dan Alkyl Benzene Sulfonat $(A B S)$ adalah surfaktan anionik yang 
merupakan senyawa aktif detergen (Doan h.d, et al., 2008). Senyawa ini memiliki rantai kimia yang sulit didegradasi (diuraikan) secara alamiah. Sesuai namanya, surfaktan bekerja dengan menurunkan tegangan air untuk mengangkat kotoran (emulsifier, bahan pengemulsi). Pada mulanya surfaktan hanya digunakan sebagai bahan utama pembuat detergen. Namun karena terbukti ampuh membersihkan kotoran, maka banyak digunakan sebagai bahan pencuci lain (R.J.Miton.,1978 ).

Surfaktan merupakan suatu senyawa aktif penurun tegangan permukaan yang dapat diproduksi melalui sintesis kimiawi maupun biokimiawi. Karakteristik utama surfaktan adalah memiliki gugus polar dan non polar pada molekul yang sama.

Surfaktan anionik Linear Alkylbenzene Sulfonate (LAS) saat ini dominan digunakan sebagai bahan aktif dalam formulasi deterjen sintetik (Jimenez et al., 1991; Campos-Garcia et al., 1999; Jerabkova et al., 1999; Huang et al., 2000; Schleheck et al., 2000; Sigoillot dan Nguyen 1992). LAS tersebut sejak tahun 1965 secara dominan digunakan dalam formulasi deterjen sintetik karena dapat didegradasi, untuk menggantikan Alkylbenzene Sulphonate bercabang $(A B S)$ yang sulit didegradasi (Lee dan Hong, 1980; Anderson et al., 1990; Marchesi et al., 1994; Schleheck et al., 2004). Konsumsi surfaktan tersebut terus meningkat dari 13 juta ton pada tahun 1977 menjadi 18 juta ton pada 1996. Surfaktan anionik LAS dalam jumlah sekitar 1,5 juta ton per tahun saat ini digunakan dalam formulasi deterjen tersebut (Vidali, 2001). Peningkatan penggunaan deterjen oleh masyarakat telah secara nyata menghasilkan limbah cair domestik yang mengandung LAS dan mencemari ekosistem sungai (Jimenez et al., 1991; Kenzaka et al., 200 1). Konsentrasi LAS di ekosistem sungai di kota besar-kota besar yang padat penduduknya khususnya di Indonesia sudah melampaui nilai ambang $0,5 \mathrm{mg} / \mathrm{L}$. Hasil penelitian menunjukkan konsentrasi LAS di air Kali Mas Surabaya pada musim kemarau 2,49-4,65 mg/L (Mitakda et al., 2000), sedangkan pada musim penghujan 0,82-1,43 $\mathrm{mg} / \mathrm{L}$ (Retnaningdyah et al., 1999). Konsentrasi LAS di air sungai sekitar pemukiman yang sedikit penduduknya antara 0,37-1,14 mg/L (Arifyanti, 2002) dan di air sungai sekitar pemukiman padat penduduk antara 4,06 -8,98 mg/L (Suharjono,2003).

Surfaktan yang terdapat dalam detergen sangat susah diurai secara biologi, hal ini secara tidak langsung akan menimbulkan dampak terhadap lingkungan yaitu lambat laun perairan yang terkontaminasi oleh surfaktan akan dipenuhi oleh busa, menurunkan tegangan permukaan dari air, pemecahan kembali dari gumpalan (flock) koloid, pengemulsian gemuk dan minyak, pemusnahan bakteri yang berguna, penyumbatan pada pori - pori media filtrasi.

Pengolahan detergen selama ini menggunakan sistem lumpur aktif secara biodegradasi, hal ini memerlukan waktu yang cukup lama serta biaya relatif besar sehingga belum efektif dalam mengolah air yang mengandung deterjen di lingkungan. Selain menggunakan sistem lumpur aktif deterjen juga bisa diolah dengan menggunakan tricling filter (Schlehek et al, 2000). Akan tetapi, metode tersebut memerlukan beberapa tahapan proses, bahan kimia, serta menghasilkan residu yang berbahaya bagi kesehatan. Oleh sebab itu, dibutuhkan suatu teknik yang lebih efektif dan efisien guna mengatasi kendala-kendala tersebut. Salah satu metode potensial untuk mendegradasi senyawa ini adalah dengan menggunakan teknik fotodegradasi memakai fotokatalis.

Penelitian ini bertujuan untuk melihat sejauh mana kemampuan semikonduktor $\mathrm{TiO} 2$ sebagai fotokatalis dalam proses fotodegradasi senyawa surfaktan yang terdapat dalam detergen menggunakan sinar UV $254 \mathrm{~nm}$. Hasil penelitian ini diharapkan dapat mengatasi dampak pemakaian detergen pada lingkungan serta memberikan masukan bagi para pengelola unit pengolahan limbah yang selama ini terbentur masalah waktu dan biaya dalam mengolah air limbah yang mengandung detergen.

\section{METODE PENELITIAN}

Alat dan Bahan

Reaktor Fotokatalis yang terdiri dari lampu uap raksa tekanan rendah $(254 \mathrm{~nm})$, neraca analitis, spektrofotometer UV-Vis, kertas saring Whatman, peralatan gelas: labu ukur, beker gelas, erlemeyer, termometer, pipet gondok, buret,dan peralatan gelas standar lainnya. Karet hisap, sarung tangan plastik dan 
kacamata juga dibutuhkan untuk keselamatan kerja di laboratorium. Bahan yang digunakan adalah Limbah Laundry, Limbah Artifisial LAS, TiO2 Anatase, Penolpetalein, HCL dan $\mathrm{NAOH}$, Metilen Blue ,Diclorometan (DCM); Na2SO4; Aquadest

Prosedur

\section{Penentuan Berat $\mathrm{TiO}_{2}$ Optimum}

Larutan LAS 100 ppm sebanyak $100 \mathrm{ml}$ dimasukkan ke dalam gelas piala kemudian ditambahkan $\mathrm{TiO}_{2}$ murni dengan variasi penambahan 0,$5 ; 1 ; 1,5 ; 2$ dan 2,5 gram. Selanjutnya disinari dengan lampu UV $254 \mathrm{~nm}$ pada dalam waktu 10 menit. Larutan hasil degradasi dipisahkan dengan centrifuge dan dianalisa dengan spektrofotometer UV-Vis. Lakukan hal yang sama terhadap larutan ABS.

Penentuan waktu Optimum

Larutan LAS 100 ppm sebanyak $100 \mathrm{~mL}$ dimasukkan ke dalam gelas piala dan tambahkan dengan $\mathrm{TiO}_{2}$ optimum kemudian disinari dengan lampu UV $254 \mathrm{~nm}$ pada variasi waktu 30,60, 90,120,150 dan 180 menit. Larutan hasil degradasi dipisahkan dengan centrifuge dan dianalisa dengan spektrofotometer UV-Vis. Lakukan hal yang sama terhadap larutan ABS.

Penentuan Serapan LAS dengan Spektrofotometer UV-Vis

Larutan LAS diukur serapannya dengan spektrometer UV-Vis mulai panjang gelombang 200 sampai 700 nm (Sanjaya Hary, 2006), Sebagai blanko digunakan aquades. Lakukan hal yang sama terhadap larutan ABS.

Penentuan Berat $\mathrm{TiO}_{2}$ Optimum

Larutan LAS 100 ppm sebanyak $100 \mathrm{ml}$ dimasukkan ke dalam gelas piala kemudian ditambahkan $\mathrm{TiO}_{2}$ murni dengan variasi penambahan 0,$5 ; 1 ; 1,5 ; 2$ dan 2,5 gram. Selanjutnya disinari dengan lampu UV $254 \mathrm{~nm}$ pada dalam waktu 10 menit. Larutan hasil degradasi dipisahkan dengan centrifuge dan dianalisa dengan spektrofotometer UV-Vis. Lakukan hal yang sama terhadap larutan ABS.

Penentuan waktu Optimum

Larutan LAS 100 ppm sebanyak $100 \mathrm{~mL}$ dimasukkan ke dalam gelas piala dan tambahkan dengan $\mathrm{TiO}_{2}$ optimum kemudian. disinari dengan lampu UV $254 \mathrm{~nm}$ pada variasi waktu 30,60, 90,120,150 dan 180 menit. Larutan hasil degradasi dipisahkan dengan centrifuge dan dianalisa dengan spektrofotometer UV-Vis. Lakukan hal yang sama terhadap larutan ABS.

Penentuan Fotodegradasi limbah cair detergen dengan Fotokatalis $\mathrm{TiO}_{2}$

Fotodegradasi limbah cair laundry dilakukan dengan limbah cair dihitung absorbansi awal dengan UV-Vis. Dengan cara melihat abosrbansi limbah pada pada panjang gelombang maksimum. Lalu lakukan fotodegradasi limbah cair dengan kondisi optimum pada sinar UV. Hasil degradasi di centrifuge lalu dipisahkan larutan analit dan ditempatkan pada kuvet UV-Vis, absorbansi hasil limbah degradasi akan terlihat pada spektrofotometer dengan melihat $\lambda$ maksimum yang dihasilkan.

Teknik Analisis Data

Data yang diperoleh berupa absorbansi larutan LAS dan ABS yang diukur dengan alat spektrofotometer UV-Vis. Analisis data dilakukan dengan melihat perbandingan absorbansi LAS dan ABS sebelum dan sesudah didegradasi. Persentase degradasi (D, \%) dihitung dengan persamaan:

$$
\mathrm{D}=\frac{A_{0}-A_{t}}{A_{0}} \times 100 \%
$$

Dimana, $A_{0}$ (cm-1) adalah absorbansi mula-mula, ${ }^{A_{t}}$ (cm-1) adalah absorbansi pada waktu $t$ (Parshetti et al., 2011).

, ..., $100 \mathrm{mg}$ ) kemudian disinari dengan lampu UV $254 \mathrm{~nm}$ selama 2 jam lalu filtrat diukur serapannya menggunakan spektrofotometer UV-Vis mulai panjang gelombang 200 sampai $700 \mathrm{~nm}$.

\section{HASIL DAN PEMBAHASAN}

Penentuan Spektrum Serapan LAS Deskripsi Data

Kepmen LH No.03 Tahun 2010 merupakan regulasi yang mengatur tentang baku mutu limbah cair, yakni kadar maksimum surfaktan yang diperbolehkan untuk dibuang kebadan air. Oleh sebab itu peraturan tersebut menjadi acuan dalam penelitian, yaitu perbandingan antara konsentrasi sampel dengan baku mutu yang disayaratkan dalam peraturan tersebut sebesar $100 \mathrm{mg} / \mathrm{L}$. Dari serangkaian penelitian yang dilaksanakan, didapatkan hasil sebagai berikut :

Penentuan $\mathrm{TiO}_{2} \quad$ Optimum Terhadap Fotodegradasi LAS 
Untuk menentukan konsentrasi optimum pemakaian $\mathrm{TiO}_{2}$ dilakukan variasi penambahan $\mathrm{TiO}_{2}$ ke dalam larutan LAS dan ABS, Adapun hasilnya dapat dilihat pada Tabel 1 dan Gambar 1.

Tabel 1 Penentuan $\mathrm{TiO}_{2}$ Optimum Terhadap Fotodegradasi LAS

\begin{tabular}{ccccc}
\hline No & $\mathrm{TiO}_{2}($ gram $)$ & $A_{0}$ & $A_{t}$ & $\% \mathrm{D}$ \\
\hline 1 & 0,5 & 2,66790 & 0,41541 & 84,42 \\
2 & 1 & 2,66790 & 0,32445 & 87,83 \\
3 & 1,5 & 2,66790 & 0,30640 & 88,51 \\
4 & 2 & 2,66790 & 0,52408 & 80,35 \\
5 & 2,5 & 2,66790 & 0,64107 & 75,97 \\
\hline
\end{tabular}

Dari data diatas terlihat penambahan jumlah katalis $\mathrm{TiO}_{2}$ dilakukan secara variatif yaitu; $0,5,1,1,5,2$ dan 2,5 gram. Setiap penambahan katalis, senyawa LAS diiradiasi menggunakan sinar UV selama 10 menit. Hasil fotodegradasi diukur dengan UV-Vis dengan panjang gelombang $571 \mathrm{~nm}$.

Dari Tabel 1 dapat dilihat bahwa dengan penambahan $\mathrm{TiO}_{2} \quad 0,5$ gram sampai pada penambahan 1,5 gram pada proses irradiasi senyawa $L A S$ menunjukkan penambahan persen degradasi berbanding lurus dengan penambahan jumlah $\mathrm{TiO}_{2}$ yang digunakan sebagai katalis, dimana konsentrasi optimum $\mathrm{TiO} 2$ yang didapatkan sebanyak 1.5 gram dengan persen degradasi $88,51 \%$. Hal ini disebabkan karena jumlah $\mathrm{TiO} 2$ didalam larutan akan mempengaruhi jumlah radikal $\mathrm{OH}$ yang terbentuk, semakin banyak $\mathrm{TiO} 2$ didalam larutan yang disinari dengan sinar UV $254 \mathrm{~nm}$ maka semakin banyak pula hole yang terbentuk nantinya. Dengan banyak hole yang terbentuk akibat eksitasi elektron dari pita valensi ke konduksi, maka semakin banyak pula radikal hidroksil yang terbentuk akibat molekul $\mathrm{OH}$ melepas satu elektronnya untuk menstabilkan hole tadi.

Pada proses irradiasi senyawa LAS dengan penambahan $\mathrm{TiO}_{2}$ sangat berpengaruh dalam penguraian senyawa LAS, menurut Fujishima, et al (2000) hal ini disebabkan absorbsi sinar UV oleh titanium dioksida akan diikuti perpindahan elektron pita valensi ke pita konduksi dimana terbentuk pasangan elektron pada pita konduksi $\left(\mathrm{e}_{\mathrm{pk}}^{-}\right)$dan lubang positif pada pita valensi $\left(\mathrm{h}_{\mathrm{pv}}^{+}\right)$.

Pada metoda fotokatalisis, radikal $\mathrm{OH}$ dihasilkan melalui oksidasi permukaan anion hidroksida dan penyerapan molekul senyawa organik pada permukaan semikonduktor $\mathrm{TiO}_{2}$ dengan adanya hole pada pita valensi. Radikal $\mathrm{OH}$ yang terbentuk akan menyerang secara reaktif senyawa LAS. Degradasi tersebut akan terus terjadi sampai kapasitas katalis tersebut tidak mampu lagi mendegradasi senyawa LAS secara optimal (Sanjaya, H. 2013).

Banyaknya $\mathrm{OH}^{-}$yang terbentuk akan meningkatkan jumlah radikal hidroksil yang berperan dalam mendegradasi $L A S$. Jadi terlihat bahwa dalam ketersediaan oksigen, substrat atau senyawa yang akan didegradasi tidak mengalami transfer muatan secara langsung tetapi melibatkan terbentuknya hidrogen peroksida lebih dahulu sebagai sumber radikal hidroksil.(Philippopoulus, et al.2008)

Hole pada $\mathrm{TiO}_{2}$ ini akan bereaksi dengan molekul $\mathrm{H}_{2} \mathrm{O}$ atau ion $\mathrm{OH}^{-}$dan memproduksi radikal hidroksil yang akan mendekomposisi senyawa LAS. Selain itu, peningkatan persentase degradasi senyawa LAS dipengaruhi oleh jumlah ion $\mathrm{H}^{+}$yang bereaksi dengan $\mathrm{O}^{-2}$ yang dapat meningkatkan jumlah $\mathrm{H}_{2} \mathrm{O}_{2}$. Dengan meningkatnya jumlah $\mathrm{H}_{2} \mathrm{O}_{2}$ maka jumlah radikal $\mathrm{OH}$ dan $\mathrm{OH}^{-}$yang terbentuk semakin besar. 


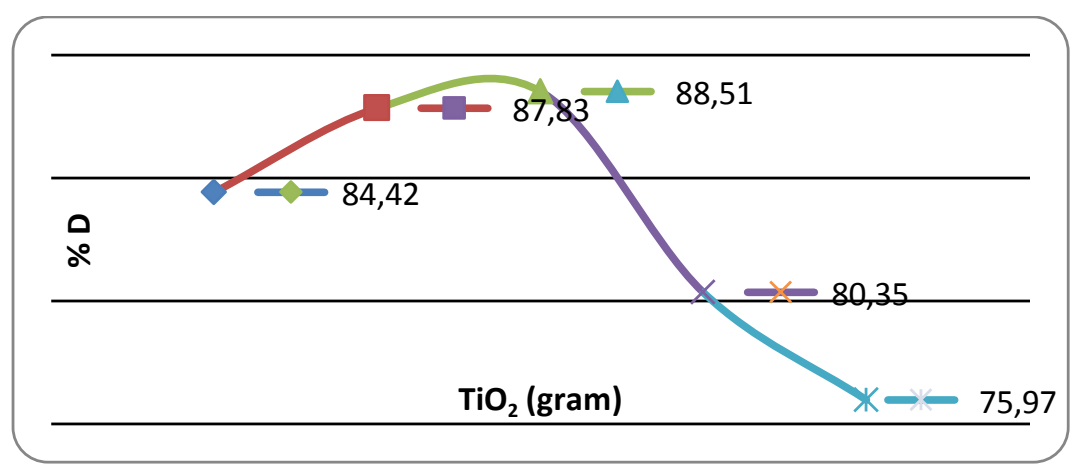

Gambar 1 Penentuan $\mathrm{TiO}_{2}$ Optimum Terhadap Fotodegradasi LAS

Dari kurva tersebut, terlihat persentase pada penambahan katalis $\mathrm{TiO}_{2} 2$ gram dan 2,5 gram mengalami penurunan. Penurunan degradasi terjadi karena penyerapan sinar UV terhalang oleh $\mathrm{TiO} 2$ yang telah berlebih dari jumlah $\mathrm{TiO} 2$ optimum yang bisa menghasilkan radikal hidroksil didalam larutan. Pada tahun 2011, Sanjaya.dkk., juga melakukan penelitian fotodegradasi LAS menggunakan $\mathrm{ZnO}$ sebagai fotokatalis dengan hasil konsentrasi optimum yang dipakai sebanyak $20 \mathrm{mg}$ terhadap LAS 10 ppm. Berdasarkan data di atas maka didapatkan penambahan katalis $\mathrm{TiO}_{2}$ optimum fotodegradasi seenyawa LAS disinari dengan lampu UV 254 sebanyak 1,5 gram.

Penentuan Waktu Optimum Terhadap Fotodegradasi LAS

Untuk mendapatkan lama waktu penyinaran dengan sinar UV $254 \mathrm{~nm}$ yang optimum maka dilakukan variasi waktu penyinaran. Hasilnya dapat dilihat pada Tabel 2 dan Gambar 2.

Tabel 2 Penentuan Waktu Optimum Terhadap Fotodegradasi LAS

\begin{tabular}{ccccc}
\hline No & Waktu (Menit) & $\boldsymbol{A}_{\boldsymbol{0}}$ & $\boldsymbol{A}_{\boldsymbol{t}}$ & \% D \\
\hline 1 & 30 & 2,66790 & 0,62216 & 76,67 \\
2 & 60 & 2,66790 & 0,52173 & 80,44 \\
3 & 90 & 2,66790 & 0,48316 & 81,80 \\
4 & 120 & 2,66790 & 0,34615 & 87,02 \\
5 & 150 & 2,66790 & 0,32132 & 87,95 \\
6 & 180 & 2,66790 & 0,21581 & 91,91 \\
\hline
\end{tabular}

Metoda fotokatalisis dalam proses kimianya menghasilkan radikal $\mathrm{OH}$ dalam larutan berair yang akan menyerang senyawa organik untuk mengawali proses mineralisasi. Selain dipengaruhi jumlah katalis juga dipengaruhi oleh lamanya waktu iradiasi. Penentuan waktu optimum penyinaran terhadap proses fotodegradasi LAS 100 ppm dilakukan dengan cara memvariasikan lama waktu penyinaran yaitu dari dari 30 menit sampai 180 menit dengan waktu berkala 30 menit. Sampel diatur pada pH optimum yaitu 3,5 (Berdasarkan penelitian Saquib, M., and Muneer, M., 2003) ditambahkan 1,5 gram $\mathrm{TiO}_{2}$ yang disinari oleh lampu UV dengan panjang gelombang $254 \mathrm{~nm}$ sambil terus diaduk. 


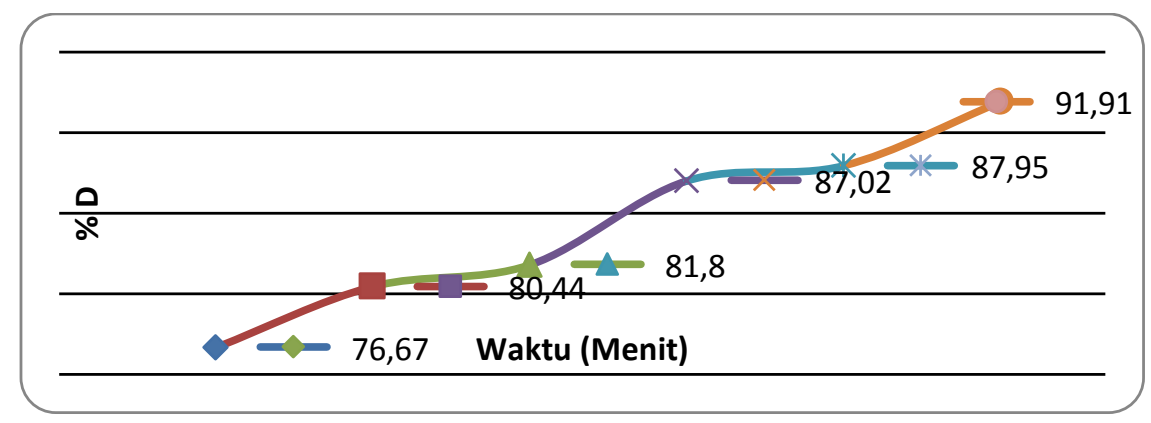

Gambar 2 Penentuan Waktu Optimum Terhadap Fotodegradasi LAS

Dari Gambar 2 diatas dapat dilihat bahwa terjadinya kenaikan persen degradasi senyawa LAS dengan bertambahnya waktu irradiasi, karena semakin lama waktu irradiasi semakin banyak jumlah radikal $\mathrm{OH}$ terbentuk yang berperan dalam mendegradasi senyawa LAS. Dari grafik tersebut tampak kenaikan persentase degradasi naik cukup signifikan, Hingga menit 120, grafik menunjukan kestabilan grafik. Hal ini terjadi karena proses degradasi tidak banyak berubah, penyebabnya adalah jumlah radikal hidroksil yang dihasilkan oleh proses fotokatalisis sudah maksimum. Walaupun lama penyinaran semakin diperpanjang tidak akan memberikan pengaruh terhadap proses pembentukan radikal hidroksil. Sesuai dengan yang telah dinyatakan oleh Fujishima (2000), dimana pembentukan radikal hidroksil sangat berpengaruh terhadap aktivitas fotokatalitik.

Penentuan $\mathrm{TiO}_{2} \quad$ Optimum Terhadap Fotodegradasi ABS.

Penentuan Konsentrasi $\mathrm{TiO}_{2}$ optimum terhadap fotodegradasi ABS juga dilakukan, dimana divariasikan jumlah $\mathrm{TiO}_{2}$ yang dimasukkan kedalam larutan ABS. Proses fotodegradasi terhadap senyawa ABS juga dilakukan dengan penambahan katalis dan melibatkan energi foton. Penambahan dilakukan secara variatif yaitu; 0,5, 1, 1,5, 2 dan 2, 5 gram. Penambahan katalis $\mathrm{TiO}_{2}$ secara optimum akan menghasilkan radikal hidoksil yang mampu menguraikan senyawa ABS menjadi senyawa yang lebih sederhana.

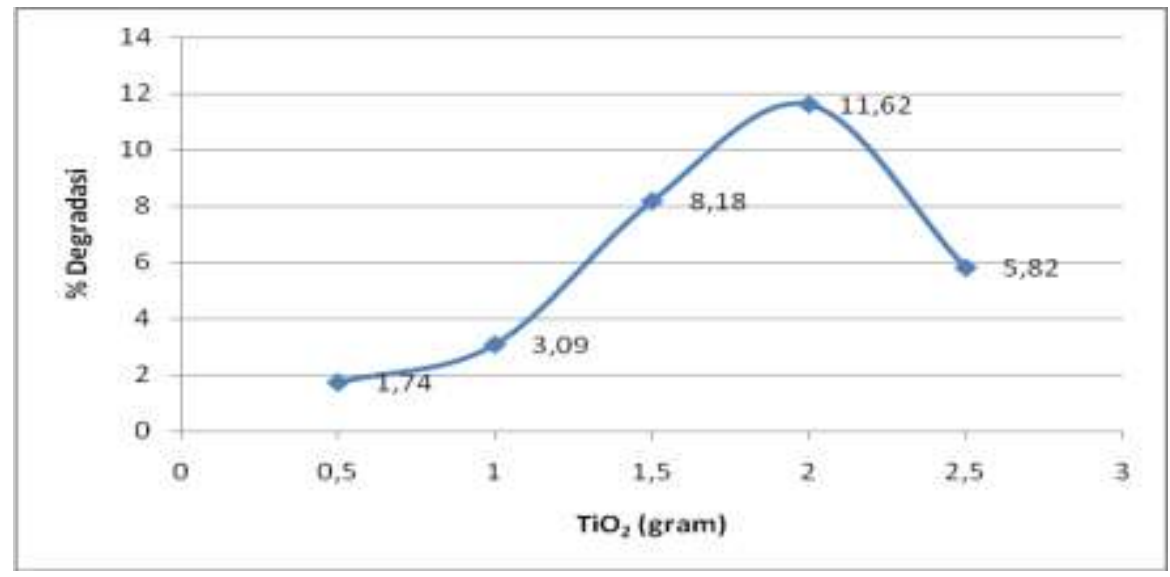

Gambar 3 Penentuan $\mathrm{TiO}_{2}$ Optimum Terhadap Fotodegradasi ABS 
Dari grafik terlihat persen degradasi dengan penambahan katalis $\mathrm{TiO}_{2} \quad 0,5$ gram sampai pada katalis $\mathrm{TiO}_{2} 2$ gram hanya terjadi sedikit mengalami kenaikan dan hanya mencapai optimal pada penambahan 2 gram yaitu sebesar 11,62\%. Pada titik penambahan $\mathrm{TiO}_{2} 2$ gram terjadi penurunan persen degradasi. Penurunan persen degradasi ini menunjukan penurunan aktivitas katalis sehingga mengurangi situs aktif katalis untuk mendegradasi senyawa ABS.

Kenaikan persentase degradasi yang sangat kecil menandakan tidak terjadi perubahan konsentrasi ABS yang signifikan. Selain karena konsentrasi ABS yang cukup tinggi, menurut hasil penelitian Slamet et al, kenaikan persen degrdasi yang kecil ini disebabkan oleh sedikitnya jumlah elektron yang mencapai permukaan katalis karena terjadinya proses rekombinasi elektron-hole yang sesuai dengan persamaan reaksi :

$\mathrm{TiO}_{2}\left(\mathrm{e}^{-} \mathrm{CB}+\mathrm{h}^{+} \mathrm{VB}\right) \longrightarrow \mathrm{TiO}_{2}+$ panas

\section{Penentuan Waktu Penyinaran Optimum Terhadap Proses Fotodegradasi ABS}

Seperti pada Fotodegradasi LAS, maka penentuan waktu penyinaran optimum pada fotodegradasi $\mathrm{ABS}$ juga dilakukan dengan memvariasikan lama waktu penyinaran larutan ABS menggunakan sinar uv $254 \mathrm{~nm}$. Hasil penelitiannya dapat kita lihat pada tabel dibawah ini

Tabel 3 Penentuan Waktu Penyinaran Optimum Terhadap Proses Fotodegradasi ABS

\begin{tabular}{ccccc}
\hline No & Waktu (Menit) & $\boldsymbol{A}_{\boldsymbol{0}}$ & $\boldsymbol{A}_{\boldsymbol{t}}$ & $\boldsymbol{\%} \mathbf{D}$ \\
\hline 1 & 30 & 2,69240 & 2,57067 & 4,52 \\
2 & 60 & 2,69240 & 2,38920 & 11,26 \\
3 & 90 & 2,69240 & 2,00470 & 25,54 \\
4 & 120 & 2,69240 & 1,13630 & 57,79 \\
5 & 150 & 2,69240 & 1,06100 & 60,59 \\
6 & 180 & 2,69240 & 0,76436 & 71,61 \\
\hline
\end{tabular}

Penentuan waktu optimum dilakukan dengan cara memvariasikan waktu iradiasi foto katalis dari ; 30, 90.120, 150 dan 180 menit. Pada 30 menit pertama sampai ke menit 90 degradasi berlangsung lambat, hal ini dikarenakan konsentrasi ABS yang digunakan cukup tinggi, sehingga membutuhkan radikal hidroksil yang lebih banyak dalam proses degradasi.

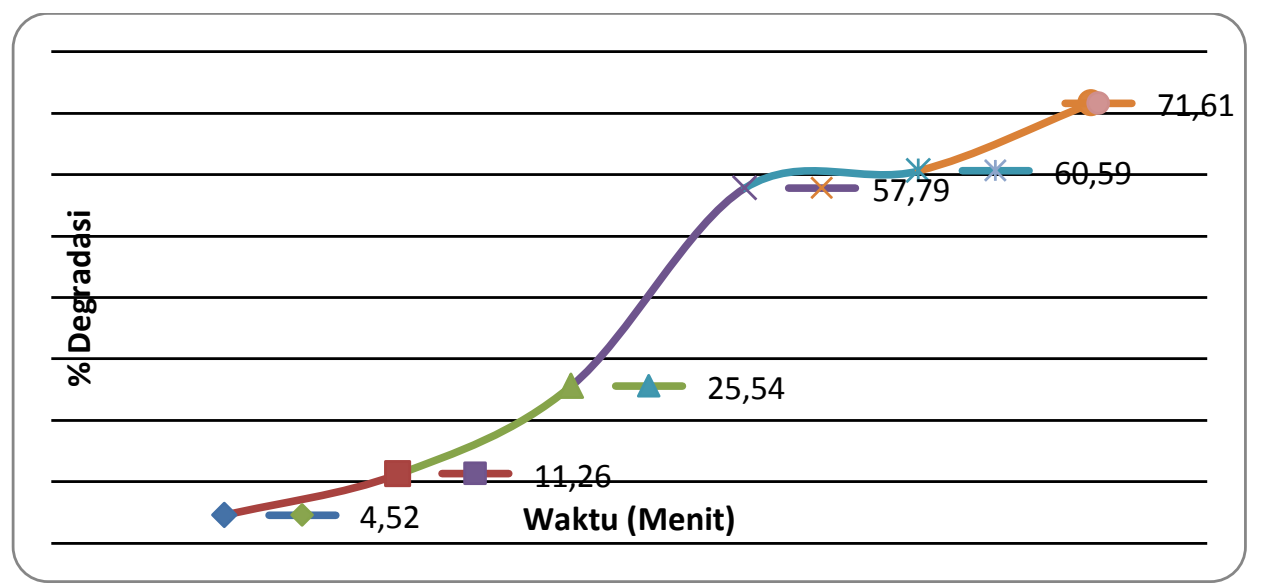

Gambar 4 Penentuan Waktu Penyinaran Optimum Terhadap Proses Fotodegradasi ABS 
Hal lain juga karena luas permukaan katalis yang digunakan selama proses fotokatalisis tetap, maka jumlah radikal $\mathrm{OH} \cdot$ yang dihasilkan oleh katalis juga akan konstan. Akibatnya akan terjadi kurangan pasokan radikal pada proses degradasi dengan konsentrasi awal yang tinggi, dan hanya akan menghasilkan tetapan kelajuan degradasi yang kecil. Pada waktu 120 menit hingga waktu 180 menit kenaikan persen degredasi tidak terlalu signifikan, sehingga waktu optimum iradiasi fotokatalis terhadap senyawa ABS adalah 120 menit dengan persen degradasi $57,79 \%$.

Fotodegradasi Menggunakan Sinar UV dengan Penambahan Katalis $\mathrm{TiO}_{2}$ pada Limbah Artifisial

Konsentrasi surfaktan yang dihasilkan oleh Laundry adalah sebesar 100 ppm. Pemerintah melalui Kepmen LH no.3 Tahun 2010 tentang baku mutu limbah cair bagi kegiatan industri, menetapkan bahwa kadar maksimum surfaktan yang diperbolehkan untuk dibuang kebadan air bagi Laundry khususnya untuk surfaktan adalah $10 \mathrm{mg} / \mathrm{L}$. Limbah laundry dan limbah artifisial dengan memiliki konsentrasi 100 ppm maka akan ditemukan perbedaan hasil pada penelitian degradasinya. Jika dibandingkan antara konsentrasi surfaktan yang dihasilkan dengan baku mutu yang ditetapkan, maka konsentrasi surfaktan dalam limbah laundry dinyatakan berada diatas baku mutu yaitu 100 ppm dan harus dilakukan pengolahan sebelum dibuang kebadan air penerima yaitu dengan mendegradasi limbah tersebut dengan fotokatalisis $\mathrm{TiO}_{2}$ anatase. Berdasarkan percobaan optimasi yang dilakukan, diperoleh kondisi optimum yaitu berat katalis 1,5 gram dan waktu penyinaran 120 menit, maka didapat efisiensi penurunan konsentrasi surfaktan pada sampel limbah artifisial sebesar $91,32 \%$ dan pada sampel limbah laundry sebesar $70,27 \%$.

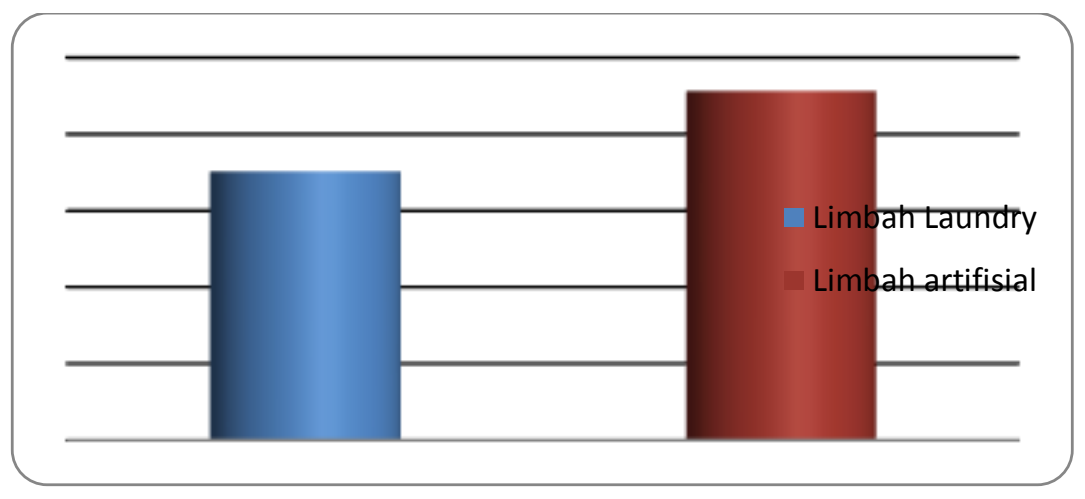

Gambar 5 Perbandingan Fotodegradasi Menggunakan Sinar UV dengan Penambahan Katalis $\mathrm{TiO}_{2}$ pada Limbah Artifisial

Dari perhitungan didapatkan persen degradasi yang cukup besar yaitu efisiensi degradasi pada limbah artifisial lebih besar dibandingkan limbah laundry itu sendiri, yang menandakan terjadinya penguraian senyawa detergen menjadi molekul yang lebih sederhana.

Pada gambar 4.6 dapat disimpulkan bahwa efisiensi degradasi dengan larutan limbah artifisial lebih tinggi dibandingkan dengan efisiensi degradasi dengan menggunakan sampel limbah laundry. Hali ini disebabkan karena pada larutan artifisial hanya mengandung senyawa LAS dan ABS, dan sedanglan pada limbah laundry mengandung terkandung senyawa-senyawa lain seperti : BOD, COD, Fosfat, dan senyawa-senyawa lainnya.

Semakin banyak yang terkandung didalam limbah laundry maka akan semakin 
sulit $\mathrm{TiO}_{2}$ anatase untuk berikatan dan berikatan juga dengan senyawa lainnya. Kondisi optimum yang didapatkan belum optimal dalam mendegradasi surfaktan dalam limbah laundry karena banyak yang menghalangi surfaktan untuk berikatan dengan $\mathrm{TiO}_{2}$ anatase.sedangkan pada limbah artifisial hanya bereaksi dengan LAS dan ABS saja sehingga reaksi terjadi dengan baik.

Aplikasi Terhadap Limbah Laundry dan Lingkungan

Masyarakat belum mengenal betul dampak yang dihasilkan oleh limbah dari industri laundry ini, dan belum memperdulikan tingkat bahayanya. Akan tetapi lambat laun dengan semakin marak atau bertambahnya industri lain bidang laundry maka akan semakin berdampak pada lingkungan. Dengan adanya penelitian ini diharapkan bisa mendapatkan pengolahan yang efektif dalam mengeliminasi dampak tersebut.

Sebahagian besar limbah yang ditimbulkan oleh kegiatan manusia dari proses produksi usaha industri laundry masih belum memperhatikan efek yang terjadi jika limbahnya dibuang sembarangan tanpa pengolahan sebelumnya. Jika limbah tersebut tidak dikelola dengan baik maka akan berdampak negatif terhadap masyarakat dan juga lingkungan disekitarnya. Adapun cara menangani dampak dari limbah tersebut adalah dengan cara mengolah atau mendegradasi limbah tersebut dari yang berbahaya menjadi tidak berbahaya, salah satunya dengan cara mendegradasi limbah laundry dengan fotokatalisis $\mathrm{TiO}_{2}$ anatase.

Banyak cara pengolahan limbah yang telah dilakukan, akan tetapi pengolahan limbah laundry menggunakan proses Fotokatalisis dengan $\mathrm{TiO}_{2}$ anatase ini merupakan langkah yang efektif untuk membuat limbah laundry diterima oleh badan air penerima, karena Fotokatalisis dengan $\mathrm{TiO}_{2}$ anatase juga dapat diaplikasikan pada industri laundry lainnya. Dengan demikian, efek buruk yang ditimbulkan dari limbah laundry akan dapat dikurangi, sehingga juga akan mengurangi dampak terhadap lingkungan pada saat sekarang dan juga mendatang.

\section{KESIMPULAN}

Berdasarkan penelitian yang telah dilakukan didapatkan beberapa kesimpulan (1) Jumlah optimum penambahan katalis $\mathrm{TiO}_{2}$ yang diperoleh dari hasil degradasi senyawa LAS secara fotokatalis adalah 1,5 gram. dan ABS sebanyak 2 gram; (2) Waktu optimum yang diperoleh dari hasil degradasi senyawa LAS dan ABS secara fotokatalis sama yaitu 120 menit; (3) Hasil degradasi dengan limbah artifisial pada kondisi optimum sebesar 91,32 \% sedangkan limbah laundry sebesar 70,27\%.

\section{DAFTAR KEPUSTAKAAN}

Behnajady, M.A., Modirshahla, N., Shokri, M., Rad, B., 2007. Enhancement of Photocatalytic Activity of $\mathrm{TiO}_{2}$ Nanoparticles by Silver Doping: Photodeposition Versus Liquid Impregnation Methods. Global NEST

Budhi, Priyanto, 2006. Uji Toksisitas Dua Jenis Surfaktan dan Detergen Komersial Menggunakan Metode Penghambat Pertumbuhan Lemna SP. Vol.7 No. 3 Hal 251- 257.

C. A. Housecroft and Alan G. Sharpe, Inorganic Chemistry, $2^{\text {nd }}-\mathrm{ed}$, Prentice Hall, England, 2005, p. 151, 596-59F.

Day,R.,danUnderwood,A.L., $\quad$ 2002， Analisi Kuantitatif Kimia (TerjemahanSopyan, I.,). Jakarta: Penerbit Erlangga. Buku asli diterbitkan tahun 1998.

F. Denger and AM Cook,. Linear alkylbenzenesulfonate (LAS) bioavailable to anaerobic bacteria as a source of sulfur. J. Appl. Microbiol. 1999. 86: 16568

Ghanbarian, M., Nabizadeh, R., Mahvi, A.H., Nasseri, S., Naddafi, K., 2011.Photocatalytic Degradation of Linear Alkylbenzene Solfunate from Aqueous Solution by $\mathrm{TiO}_{2}$ Nanoparticle, Iran Journal of Environmental Health Science English,Vol.8, No.4, pp 309-316.

Keputusan Menteri Negara Lingkungan Hidup Nomor : Kep-03/MENLH/2010 tentang Baku Mutu Limbah Cair Bagi Kegiatan Industri.

Philippopoulos, C.J., and Nikolaki, M.D., 2008. Photocatalytic Processes on theOxidation of Organic Compounds in 
Water. National Technical University of Athens, Chemical Porcess Engineering Laboratory: Greece. Vol.6, pp

Sanjaya, Hary.,Hermansyah Aziz, Syukri. 2013. Fotodegradasi surfaktan linear alkyl sulfonat (LAS) menggunakan sinar $U V$ $254 \mathrm{~nm}$ dengan bantuan $\mathrm{ZnO}$ sebagai katalis. Jurnal sainstek Universitas Gorontalo. 2013.

Sastrawijaya, A. Tresna. Pencemaran Lingkungan. Jakarta : Rineka Cipta. 1991.
Schleheck, Dong W, K. Dnger, E. Heinzle and AM Cook,.An a-Proteobacterium Converts Linear AlkylbenzenesulfonateSurfactants into Sulfophenylcarboxylates and Linear Alkyldiphenyletherdisulfonate Surfactants into Sulfodiphenylethercarboxylates. Applied. and Env. Microb. 2000.Vol 66. (5): 1911-16. 